\title{
Analiza zabudowy układu przeciwpoślizgu z uwzględnieniem potencjalnych błędów konstrukcyjnych i eksploatacyjnych
}

\begin{abstract}
$W$ artykule przedstawiono stosowane rozwiazania układów przeciwpoślizgowych instalowanych na wózkach pojazdów szynowych. Wyodrębniono i scharakteryzowano rozwiqzania, które sq obecnie stosowane. Określono miejsca powstawania potencjalnych błędów wykonawczych wpływajacych na zniekształcania sygnału generowanego w czujniku (nadajniku impulsów). Określono również miejsca powstawania błędów i ich wptyw na działanie układu przeciwpoślizgu w okresie eksploatacji.Podjęto próbę analizy wplywu $w / w$ parametrów na jakość sygnału i na niezawodność dziatania uktadu wykonawczego (eliminację zjawiska poślizgu kót względem szyny). Przedstawiono algorytmy postępowania zmierzajqce, poprzez rozpoznanie miejsca powstawania błędu, do eliminacji zjawiska i maksymalnego wykorzystania możliwości jakie daje stosowany rodzaj układu przeciwpoślizgowego.

Artykul powstal $w$ ramach projektu badawczo-rozwojowego $\mathrm{Nr} R \quad 10$ 004806/2009 pt. „,Mikroprocesorowy system diagnostyczny głównych systemów trakcyjnego pojazdu szynowego uwzględniajacy ocenę bieżaca i prognozowanie stanów", finansowanego z budżetu Ministerstwa Nauki i Szkolnictwa Wyższego.
\end{abstract}

\section{Wprowadzenie}

Eksploatacja pojazdu szynowego związana jest $\mathrm{z}$ zagadnieniem występowania kontaktu koło-szyna. Na styku tych elementów generują się siły dynamiczne mające wpływ na zachowanie się całego pojazdu podczas ruchu.

Dbałość o właściwą współpracę tych dwóch elementów wydaje się jednym $\mathrm{z}$ podstawowych kryteriów, uzasadniających stosowanie różnego rodzaju zabiegów wpływających na właściwe wykorzystanie stanu powierzchni koła i szyny.

Właściwa praca dynamiczna pojazdu opiera się na racjonalnym doborze siły napędowej i hamowania pojazdu. W przypadku zwiększenia siły napędowej pojazdu, a tym samym jego przyspieszenia lub zwiększenia zdolności pociagowej musi ulec zwiększeniu zdolność jego hamowania. W związku z tym (ze względu na ograniczoną przyczepności kół pojazdu w kontakcie $\mathrm{z}$ szyną) należy dążyć do maksymalnego wykorzystania tego zjawiska. Wykorzystanie siły przyczepności zależy od różnych czynników takich jak stan powierzchni szyn, stan techniczny toru, warunki pogodowe. Czynniki te zmieniają się w sposób przypadkowy i mają charakter losowy [4].

Warunek istnienia ruchu obrotowego koła po szynie można wyrazić następującym wzorem:

$$
\mathrm{P}=\mu_{\mathrm{S}} \cdot \mathrm{G}_{\mathrm{Z}}
$$

gdzie:

$\mu_{\mathrm{S}}$ - współczynnik przyczepności,

$\mathrm{G}_{\mathrm{Z}}$ - nacisk zestawu kołowego na tor.

W razie nagłego obniżenia przyczepności poniżej wartości siły tarcia elementów ciernych, warunek ruchu obrotowego zestawów kołowych zostaje naruszony, wystapi $\mathrm{w}$ tym przypadku zmiana nierówności na:

gdzie:

$$
\mu_{\mathrm{t}} \cdot \mathrm{N}_{\mathrm{Z}}>\mu_{\mathrm{s}} \cdot \mathrm{G}_{\mathrm{Z}}
$$

$\mu_{\mathrm{t}}$ - współczynnik tarcia,

$\mathrm{N}_{Z}$ - łączny nacisk elementów par ciernych przypadających na zestaw kołowy.

W chwili zatrzymania ruchu obrotowego zestawów kołowych ruchowi pojazdu przeciwstawia się stosunkowo nieznaczna siła tarcia ślizgowego kół po szynach. Towarzyszy temu znaczne zmniejszenie efektywności hamowania.

Zadaniem układów przeciwpoślizgowych jest wykrywanie tego zjawiska w jak najkrótszym czasie oraz jego skuteczne likwidowanie.

Rozróżniamy następujące typy układów przeciwpoślizgowych:

- mechaniczno-pneumatyczne - wykorzystujący masy wirujące do pomiaru opóźnienia ruch obrotowego zestawu kołowego (układ taki działa bezpośrednio na układ pneumatyczny hamulca - obecnie nie są już stosowane), 
- pneumatyczno-elektroniczne (mechatroniczne) - gdzie układem pomiarowym jest czujnik prędkości zestawu kołowego montowany na osi, połączony sygnałowo z urządzeniem sterującym pojazd szynowy. Zarządzanie układem wykonawczym może odbywać się w takim przypadku za pomocą różnego rodzaju procedur (algorytmów) mogących działać na układ wykonawczy (pneumatyczny) na zasadzie przewidywań przypuszczalnych stanów kontaktu koło-szyna.

Najczęściej wykorzystywane układy przeciwpoślizgowe bazują na pomiarze prędkości obrotowej zestawu kołowego za pomocą czujników bezstykowych współpracujących z kołem zębatym montowanym na osi zestawu kołowego.

Właściwa współpraca pary pomiarowej koło zębateczujnik ma duże znaczenie na jakość generowanego sygnału, który w późniejszym etapie jest przetwarzany przez urządzenie sterujące pracą układu napędowego oraz hamulcowego.

\section{Współczesne układy przeciwpoślizgowe}

Obecnie stosowane rozwiązania układów przeciwpoślizgowych są rozbudowanymi układami regulacji działającymi w czasie rzeczywistym, które w sposób dynamiczny nadzoruja cały system przeniesienia napędu.

Układy te wykorzystują czujniki bezstykowe (optyczne bądź magnetyczne-reluktancyjne) do pomiaru prędkości obrotowej zestawu kołowego, Zaletą tego typu rozwiazzań jest ich bezobsługowa praca. Warunkiem koniecznym dla prawidłowego działania jest właściwa zabudowa tych urządzeń względem osi zestawu kołowego. Dodatkową zaletą tego typu czujników jest możliwość zmiany parametrów sygnałów generowanych, które mogą być dobierane stosownie do układów współpracujących.

Czujniki wykorzystywane do pomiaru można podzielić na dwie grupy:

- czujniki zespolone z własnym układem generującym impulsy,

- czujniki pomiarowe, które wykorzystują koło zębate jako generator impulsów.

Zaletą drugiej grupy czujników jest ich wszechstronność zastosowania dla różnych prędkości obrotowych kół pojazdów szynowych oraz średnic. Posiadają niewielkie wymiary gabarytowe $\mathrm{w}$ stosunku do czujników zespolonych. Montowane są w kierunku promieniowym w stosunku do osi pojazdu szynowego, najczęściej w pokrywie maźnicy. Takie miejsce montażu jest optymalne ze względu na dostępność oraz nie kolidowanie $\mathrm{z}$ innymi elementami montowanymi na maźnicy.
Wadą tych czujników jest konieczność przygotowania miejsca współpracy z osią pojazdu oraz zaprojektowanie dodatkowego elementu generującego impulsy dla czujnika w postaci koła zębatego o dużej tolerancji wykonania uzębienia.

\section{Parametry określające właściwą współpracę pary koło zębate - czujnik prędkości.}

Do właściwej współpracy pary czujnik koło zębate potrzebne jest spełnienie kilku podstawowych warunków dotyczących wzajemnego położenia oraz kształtu geometrycznego koła zębatego:

- zachowanie odpowiedniego profilu kształtu zęba oraz szerokości koła zębatego

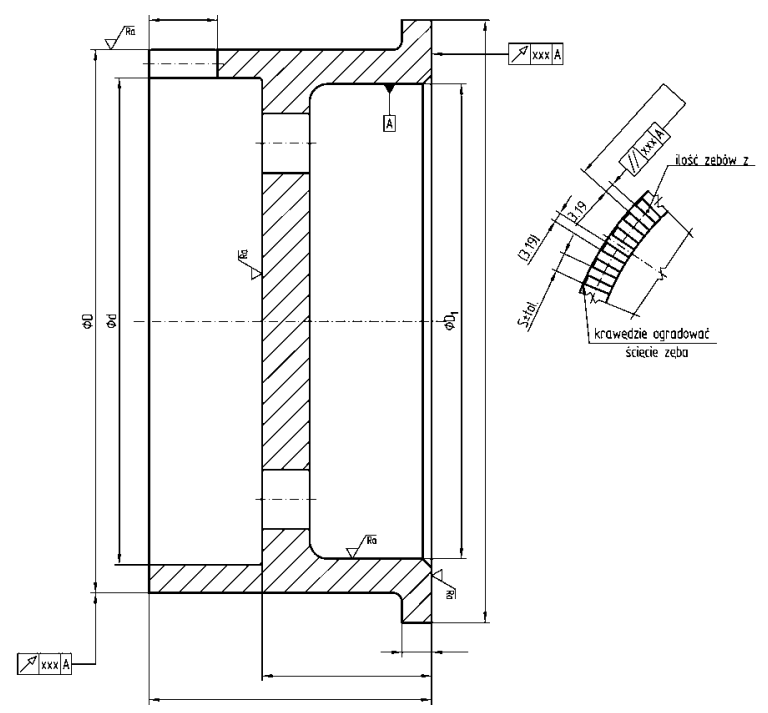

Rys.1 Przykład konstrukcji zębatki koła pomiarowego uwzględniający tolerancję kształtu i położenia [5]

- właściwa dla danego czujnika szczelina pomiędzy kołem zębatym a czujnikiem dostosowana do danego typu czujnika

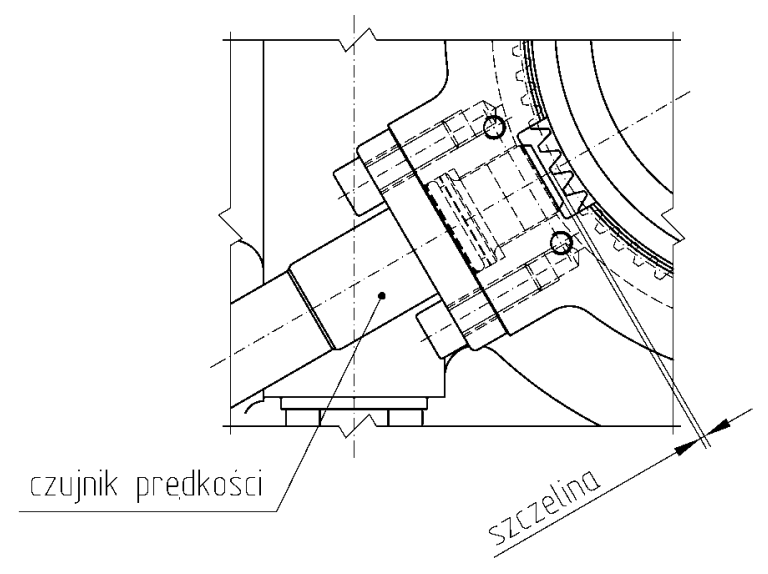

Rys.2 Przykład zabudowy czujnika prędkości na korpusie maźnicy $\mathrm{z}$ otworem służącym do kontroli i regulacji położenia czujnika względem koła zębatego [5] 
- właściwy dobór ilości zębów, tak aby min. i max. zakres generowanej częstotliwości sygnału wyjściowego mieścił się w granicach dopuszczalnej częstotliwości pomiarowej czujnika [1],

$$
\mathrm{f}_{\text {max }}>\mathrm{f}_{\text {czujnika }}=\frac{\mathrm{V} \cdot \mathrm{Z}}{\pi \cdot \mathrm{D}}
$$

gdzie:

$\mathrm{f}_{\max }$ - maksymalna dopuszczalna częstotliwość pomiarowa czujnika $[\mathrm{Hz}]$,

$\mathrm{f}_{\text {czunina }}$ - częstotliwość generowanego sygnału [Hz],

$\mathrm{V}$ - prędkość maksymalna pojazdu $[\mathrm{m} / \mathrm{s}]$,

Z - liczba zębów koła zębatego,

D - średnica koła pojazdu.

- właściwy wybór miejsca montażu czujnika, tak aby nie kolidował z innymi elementami węzła maźnicznego oraz aby możliwy był dostęp do kontroli i ewentualnej regulacji szczeliny,

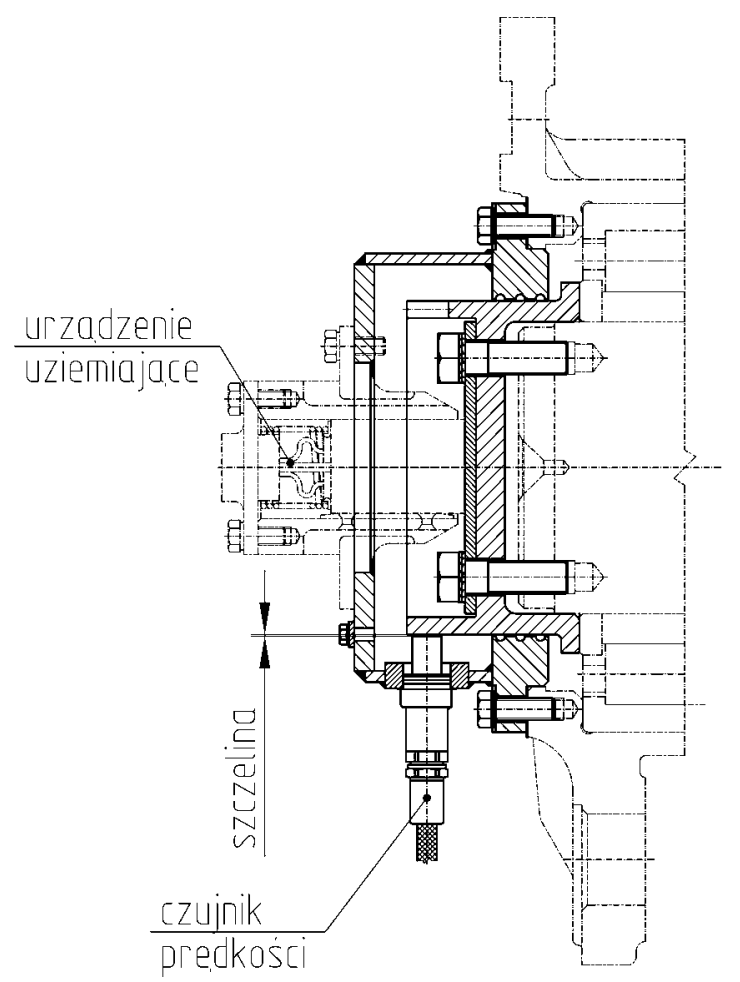

Rys.3 Przykład zabudowy czujnika prędkości na korpusie maźnicy uwzględniający montaż dodatkowych urządzeń na porywie maźnicy [5]

- właściwy dobór materiału na koło zębate tak aby koło zębate nie wykazywało właściwości magnetycznych podczas eksploatacji.

\section{Miejsca powstawania błędów i ich wpływ na działanie układu}

Potencjalnymi miejscami powstawania błędów wpływających na działanie układu pomiaru prędkości obrotowej zestawu kołowego są wymienione w punkcie 3 parametry geometryczne i materiałowe jakie powinny być zachowane do właściwej współpracy tej pary.
4.1. Zachowanie odpowiedniego profilu kształtu zęba oraz szerokości koła zębatego.

Podczas badań układów przeciwpoślizgowych w IPS ,Tabor" [2] z wykorzystaniem do pomiaru prędkości obrotowej kół zestawów kołowych czujników współpracujących $\mathrm{z}$ pierścieniem zębatym zauważono, że duże znaczenie ma właściwie wykonanie tego elementu układu pomiarowego i to zarówno pod względem jakości powierzchni głów zębów jak i parametrów tolerancji jego kształtu i położenia. Przy szerokości głowy zęba $5 \mathrm{~mm}$, błąd rzędu $0,1 \mathrm{~mm}$ stanowi odchylenie mierzonej prędkości o $2 \%$. Przy niedokładnym wykonaniu uzębienia pomiar pojedynczego odstępu między dwoma sąsiednimi zębami obarczony jest dość poważnym błędem. Skutkuje to zakłóceniami niemożliwymi do zlikwidowania przez algorytm pomiarowy układu, gdyż występuje on podczas pomiaru w sposób przypadkowy. Na rys.4 przedstawiono przebieg 6osiowej lokomotywy rejestrowany bez filtracji, przy niedokładnym wykonaniu uzębienia koła pomiarowego.

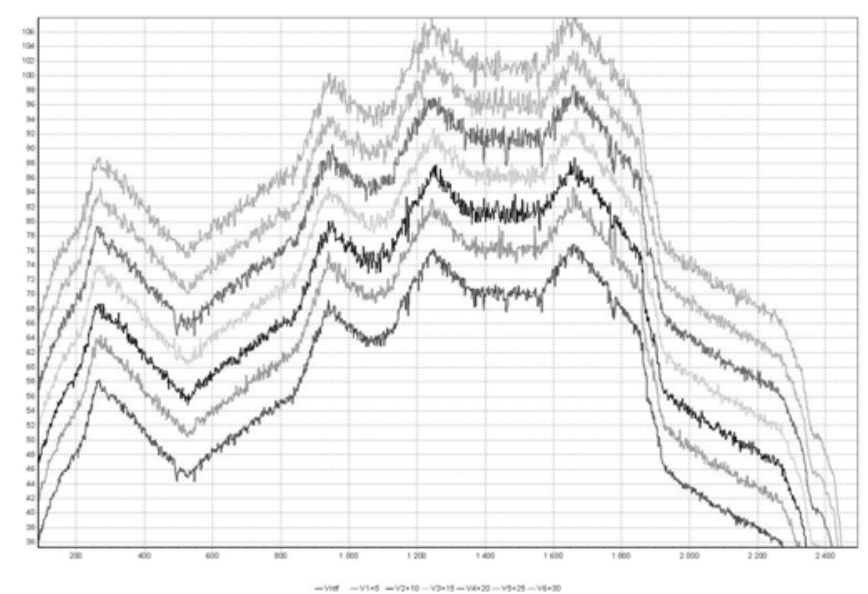

Rys.4 Przebiegi prędkości obarczone błędem wynikającym z niedokładności w wykonaniu zębatek [2]

4.2 Właściwy dobór materiału na koło zębate tak aby koło zębate nie wykazywało właściwości magnetycznych podczas eksploatacji.

Szczątkowe właściwości magnetyczne jakie może wykazywać materiał koła zębatego mogą powodować przyciaganie zanieczyszczeń metalowych w postaci opiłków i kawałków metalu. Zanieczyszczenia te mogą pojawić się na skutek procesu zużywania się elementów znajdujących się w bezpośredniej bliskości pary czujnik-zębatka, do których należą np. łożyska maźnicy.

Zanieczyszczenia te w niekorzystnych warunkach moga doprowadzić do okresowego zaniku sygnatu generowanego w czujniku.

$\mathrm{Na}$ rys.5 przedstawiono przebieg prędkości $\mathrm{z}$ zarejestrowanym zanikiem prędkości na jednej osi. 


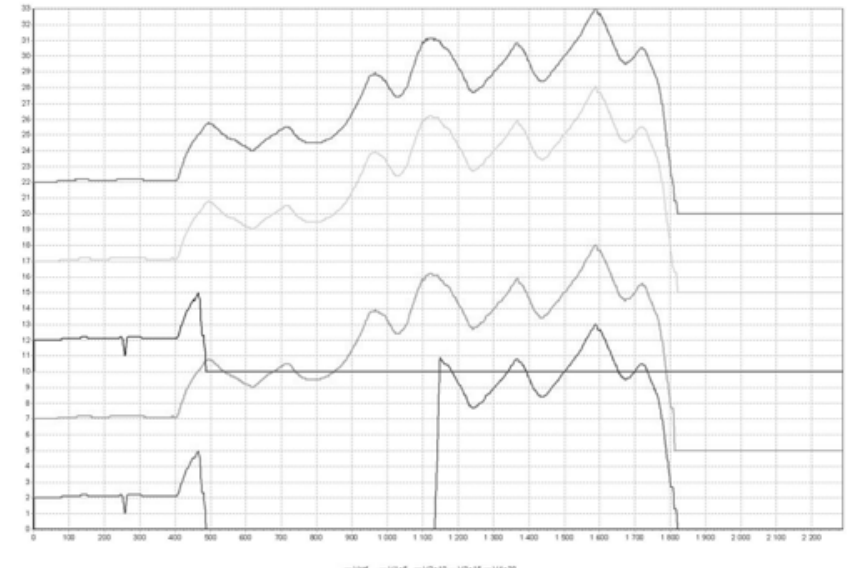

Rys.5 Przebieg prędkości z zarejestrowanym zanikiem prędkości na jednej osi.[2]

4.3 Właściwa dla danego czujnika szczelina pomiędzy kołem zębatym a czujnikiem dostosowana do danego typu czujnika [3] .

Szczelina, którą ustawia się podczas regulacji czujnika względem koła zębatego ma wartość stałą. Przy ustalaniu wielkości tej szczeliny należy wziąć pod uwagę kilka kryteriów, które należy uwzględnić przy doborze wielkości luzu pomiędzy czujnikiem a kołem zębatym. W rzeczywistości szczelina pomiędzy współpracującymi elementami układu pomiarowego zmienia się $\mathrm{w}$ pewnych granicach. Dlatego przy wyborze wielkości luzu należy zbadać wszystkie czynniki, które mogą mieć wpływ na zmianę jego wielkości.

Maksymalna amplituda przemieszczenia względnego jest sumą amplitud cząstkowych pochodzących od (podane miejsca powstawania przesunięć pochodzą od klasycznego układu maźnicznego z łożyskiem wałeczkowym i pierścieniem dociskowym, na którym zabudowana jest zębatka pomiarowa) :

- niewspółosiowego położenia pierścienia dociskowego, - amplituda ta może osiagnąć wartość równą połowie luzu pasowania pierścienia na czopie osi,

- promieniowego bicia własnego pierścienia dociskowego, - amplituda ta może osiagnąć wartość równą połowie tolerancji bicia tego pierścienia,

- niewspółśrodkowego położenia koła zębatego względem pierścienia dociskowego, amplituda ta może osiagnąć wartość równą połowie luzu pasowania koła zębatego na pierścieniu dociskowym,

- promieniowego bicia własnego koła zębatego, amplituda ta jest równa połowie bicia promieniowego,

- wężykowania zestawu kołowego w granicach luzów promieniowych łożysk maźnicznych.
Właściwy dobór szczeliny pomiędzy czujnikiem a kołem zębatym powinien uwzględniać sumę wielkości luzów jakie powstają w układzie gdzie zamontowany jest czujnik. Dla obecnie montowanych układów czujnik-koło zębate najczęściej stosuje się luzy $\mathrm{w}$ granicach $1,2 \mathrm{~mm} \mathrm{z}$ tolerancją $\pm 0,2 \mathrm{~mm}$ przy module koła zębatego $\mathrm{m}=2$.

\section{Postępowania w celu zmniejszenia wpływu błę- dów wykonawczych i montażowych.}

$\mathrm{W}$ przedstawionych w punkcie 4 miejscach powstawania błędów i ich wpływu na generowany sygnału wywnioskować można, że najwłaściwszą drogą do poprawienia sygnału w czujniku jest eliminacja błędów wykonawczych koła zębatego. Koło w takim układzie traktować należy jako element o charakterze precyzyjnym.

W celu eliminacji błędów pomiarowych można zaproponować kilka algorytmów postępowania:

w przypadku wystapienia $\mathrm{w}$ obrazie sygnału zakłóceń wynikających z przebiegu prędkości obarczonych błędem wynikającym z iedokładności w wykonaniu zębatek (jak na rys.4) należy zastosować dokładniejszą obróbkę powierzchni średnicy zewnętrznej koła zębatego, w tym celu stosuje się dodatkową obróbkę zmniejszająca chropowatość średnicy zewnętrznej koła zębatego, stąd najczęściej średnica zewnętrzna tego koła ma mniejszą średnice niż wynikałoby to $\mathrm{z}$ wzorów na zależności geometryczne koła zębatego (powiązanie średnic koła zębatego $\mathrm{z}$ modułem $\mathrm{i}$ ilością zębów),

w przypadku wystapienia przebiegów wynikających $\mathrm{z}$ przebiegu prędkości z zarejestrowanym zanikiem prędkości na jednej osi (jak na rys.5) należy przeanalizować miejsce montażu czujnika i koła zębatego, powodem tego może być znajdowanie się w bezpośredniej bliskości czujnika miejsc powstawania i wytrącania się zanieczyszczeń, które powodują niekontrolowaną zmianę wartości strumienia magnetycznego, częstą przyczyną występowania zakłóceń sygnału są niedokładności w konstrukcji i montażu pierścienia zębatego na osi zestawu kołowego. Dążyć należy w takim przypadku do jak najmniejszej liczby wzajemnych połączeń pasowanych pomiędzy zamocowaniem tego elementu a osia zestawu kołowego. Niekiedy wybór sposobu montażu zębatki pomiarowej do osi zdeterminowany jest konstrukcją pokrywy maźnicy. Dzieje się tak najczęściej w przypadku modernizacji istniejących rozwiązań konstrukcyjnych węzłów maźnicznych $\mathrm{w}$ zakresie zabudowy przeciwpoślizgowych układów pomiarowych. W tym przypadku zakłócenia sygnału mogą mieć charakter bardziej złożony. 


\section{Podsumowanie i wnioski}

$\mathrm{Z}$ przeprowadzonych $\mathrm{w}$ artykule analiz rozwiązań konstrukcyjnych stosowanych układów przeciwpoślizgowych wykorzystujących do pomiaru czujnik magnetyczny i koło zębate jako generator impulsów, wnioskować można, że właściwa praca takiego układu pomiarowego obarczona jest dużą ilością czynników je zakłócających. Od rozpoznania i określenia ich wpływu na układ należy rozpoczać dostosowywanie układu pomiarowego do danego rozwiązania konstrukcyjnego.

W przypadku uruchomienia układu pomiarowego sygnał odczytywany można zinterpretować pod kątem występujących w nim zakłóceń i dopasować do niego odpowiednią metodę obliczeniową dla układu sterującego. Część zakłóceń pochodzących od wadliwego wykonania układu nie może być jednak niwelowana za pomocą kolejnych uśrednień i filtracji przez układ obliczeniowy. Doprowadzać to może w konsekwencji do pojawiania się niekontrolowanych sygnałów mających charakter losowy, a przez to do niewłaściwego rozpoznania stanu w miejscu styku koło-szyna. Właściwa zabudowa układu czujnik-pierścień zębaty pod względem mechanicznym skutkuje również prostszym układem obliczeniowym

Pojawianie się zakłóceń w generowanym sygnale może mieć dodatkowe zastosowanie takiego układu pomiarowego. Sygnał, który jest generowany w czujniku ma postać analogową. Jego wartość i przebieg zależy w dużej mierze od czynników go zakłócających. Czynniki wpływające na zakłócenia sygnału wzorcowego generowanego w czujniku można również wykorzystać do określania stanów technicznych np. układu łożyskującego zestaw kołowy. Do tego celu posłużyć może rozbudowany układ pomiarowy ukierunkowany na wykrywanie odmiennych stanów od założonych na drodze przeprowadzonych wcześniej analiz teoretycznych i eksperymentalnych.

\section{Literatura:}

[1] Barna G., Stypka M. OR-8268 „Dobór czujników prędkości dla uktadu likwidacji poślizgu" Instytut Pojazdów Szynowych w Poznaniu listopad 2000r,

[2] Cierniewski M. OR-9742 „Zakłócenia prędkości pomiarowej, sposoby odktócania i wybór zastosowanej metody filtrowania" Instytut Pojazdów Szynowych w Poznaniu styczeń 2011r,

[3] Dolański J. „Analiza wymiarowa zabudowy nadajnika prędkości należacego do uktadu przeciwpoślizgowego lokomotywy sześcioosiowej typu 303D" Instytut pojazdów Szynowych w Poznaniu materialy szkicowe - 2012r,

[4] Kalinkowski A., Orlik A. „Wagony kolejowe i hamulce” WKiE Warszawa 1981r.

[5] Miklasz R. Instytut Pojazdów Szynowych w Poznaniu prace własne realizowane przy konstrukcji ukladów pomiarowych. 